\title{
ЭКОНОМИЧЕСКАЯ И СТАТИСТИЧЕСКАЯ ОЦЕНКА ПРОБЛЕМЫ АЛКОГОЛЬНОЙ ЗАВИСИМОСТИ В РОССИИ (РЕГИОНАЛЬНЫЙ АСПЕКТ)
}

\author{
Ю.Е. Шматова (https://orcid.org/0000-0002-1881-0963) \\ Вологодский научный иентр РАН, Вологда, Россия, \\ e-mail:ueshmatova@mail.ru
}

Массовое распространение алкоголизма признано одной из главных угроз национальной безопасности. Экономические потери за 2016 г. вследствие вредного употребления алкоголя в мире составили 99 млн лет «здоровой» жизни (DALY). В статье выявлено, что экономический ущерб вследствие смертности и инвалидности от негативных последствий алкоголя в РФ в три раза выше среднемировых значений. По сравнению с 1990 г. увеличилось «бремя болезни», как и смертность по указанной причине среди молодежи. В исследовании алкоголизация населения представлена в качестве системы статистических показателей. Отражена их динамика в постсоветский период (с акцентом на Северо-Западном федеральном округе и Вологодской области). Отмечены позитивные тренды снижения заболеваемости алкоголизмом и алкогольными психозами, смертности от случайных алкогольных отравлений, сокращения объемов продаж спиртных напитков. Выделены регионы лидеры по алкоголизму. Вологодская область демонстрирует значительное превышение уровня распространения алкогольных психозов, что говорит о слаборазвитой системе лечения и реабилитации лиц, страдающих алкоголизмом.

Ключевые слова: алкоголизм, заболеваемость алкогольными психозами, смертность от случайных отравлений алкоголем, бремя болезни, продажа спиртных напитков.

\section{ECONOMIC AND STATISTICAL EVALUATION OF THE PROBLEM OF ALCOHOL DEPENDENCE IN RUSSIA (REGIONAL ASPECT)}

\author{
Yu.E. Shmatova \\ Vologda research center of Russian academy of sciences, Vologda, Russia, \\ e-mail:ueshmatova@mail.ru
}

Mass distribution of alcoholism is recognized as one of the main threats to national security. The economic loss in 2016, the result of harmful use of alcohol 
in the world was 99 million years of «healthy» life (DALY). The article revealed that alcohol in the Russian Federation is three times higher than the world average. Compared to 1990, the "burden of disease" increased, as did the death rate for this reason among young people. In the article, the alcoholization of the population is presented as a system of statistical indicators. Reflects their dynamics in the post-Soviet period (with an emphasis on the North-West Federal District and the Vologda region). Positive trends were noted in reducing the incidence of alcoholism and alcohol psychosis, mortality from accidental alcohol poisoning, and the reduction in sales of alcoholic beverages. Allocated regions leaders in alcoholism. Vologda region demonstrates a significant excess of the level of distribution of alcoholic psychosis, which indicates an underdeveloped system of treatment and rehabilitation of people suffering from alcoholism.

Keywords: alcoholism, the incidence of alcoholic psychosis, mortality from accidental alcohol poisoning, the burden of disease, the sale of alcoholic beverages. DOI 10.14258/ssi(2019)3-6361

\section{Введение}

Массовое распространение наркомании и алкоголизма признано одной из главных угроз национальной безопасности в сфере здравоохранения и здоровья нации ${ }^{1}$. Одной из приоритетных задач повышения качества жизни россиян является снижение уровня заболеваемости алкоголизмом и наркоманией, обеспечение доступности современного здравоохранения, в том числе наркологической помощи.

Люди, страдающие алкогольной зависимостью, повышают число социально не адаптированных людей, а значит, не могут полноценно принимать участие в общественной жизни. Несмотря на то что алкоголизм является медицинским диагнозом, его причины и последствия зачастую социально-экономические.

По данным Всемирной организации здравоохранения ${ }^{2}$ ежегодно в мире около 3 миллионов смертей (5,3\% всех случаев) происходит вследствие вредного употребления алкоголя. Причем среди молодежи (в возрасте 20-39 лет) их доля выше 13,5\% смертей, среди мужчин - 7,7\%, а женщин - 2,6\%. В 2016 г. в мире насчитывалось более 100 миллионов случаев алкогольной зависимости. Вредное употребление алкоголя стало причиной смерти от 2 до 8 миллионов человек (или от 228 до 913 смертей в час) (Degenhardt et al., 2018: 994).

Злоупотребление спиртными напитками вызывает более 200 нарушений здоровья, в том числе репродуктивного, что особенно опасно на фоне демографической проблемы. Употребление алкоголя увеличивает риск непреднамеренных и преднамеренных травм, а также неинфекционных и инфекционных заболеваний (Rehm et al., 2017; Rehm et al., 2010). Так, в Великобритании по прогнозу специалистов

\footnotetext{
1 Стратегия национальной безопасности Российской Федерации до 2020 года. Официальный сайт Президента РФ. URL: http://kremlin.ru/supplement/424 (дата обращения: 01.07. 2019).

2 Сведения о смертности населения по причинам смерти в Российской Федерации за январь-декабрь 2018 года. URL: http://www.gks.ru/free_doc/2018/demo/t3_3.xls (дата обращения: 01.07. 2019).
} 
к 2020 г. заболевания печени должны превзойти болезни сердца в качестве основной причины смерти (Gray, 2018).

Потребление алкоголя с вредными последствиями дает существенную нагрузку на систему здравоохранения, порождая прямые медицинские издержки, а также расходы, связанные со страхованием, правоохранением, общественным порядком и деятельностью на рабочих местах. Все это оказывает негативное воздействие на различные социальные аспекты жизни, общественное благополучие и экономическое развитие в целом. Немаловажно, что человек, страдающий алкогольной зависимостью, не только разрушает собственную жизнь, но и значительно ухудшает качество жизни близких людей. Супруги зависимых лиц чаще страдают нервно-психическими расстройствами. Дети, выросшие в таких семьях, чаще повторяют судьбу пьющих родителей.

«Цена» алкоголизма. Экономическое бремя болезни рассчитывается с помощью показателя DALY. Один DALY может считаться одним потерянным годом «здоровой» жизни. Сумма этих DALY среди населения (или бремя болезни) — измерение разрыва между текущим состоянием здоровья и идеальной ситуацией, когда все население живет до преклонного возраста, без болезней и инвалидности. DALY рассчитываются как сумма потерянных лет жизни вследствие преждевременной смертности (YLL) и вследствие инвалидности (YLD).

По данным масштабного международного исследования общее бремя болезней и травм, обусловленных алкоголем (в том числе непреднамеренные травмы, самоубийства, алкогольные заболевания сердечно-сосудистой и пищеварительной системы, рак и цирроз), составило в 2016 г. 4,2\% глобального бремени болезней (ГББ) (Degenhardt et al., 2018).

Рост населения и его старение привело к тому, что с 1990 года число людей с расстройствами, связанными с употреблением алкоголя и наркотиков, значительно возросло (таблица 1). Тем не менее в связи с развитием медицины бремя болезни за указанный период несколько снизилось. Стандартизированная по возрасту распространенность среди мужчин в 2 раза выше, чем среди женщин.

Таблица 1

Распространенность заболеваний, связанных с употреблением алкоголя (Degenhardt et al., 2018)

\begin{tabular}{c|c|c|c|c}
\multirow{2}{*}{ Категории } & \multicolumn{2}{|c|}{$\mathbf{1 9 9 0}$ г. } & \multicolumn{2}{|c}{2016 г. } \\
\cline { 2 - 5 } & Млн случаев & $\begin{array}{c}\text { На 100 тыс. } \\
\text { населения }\end{array}$ & Млн случаев & $\begin{array}{c}\text { На 100 тыс. } \\
\text { населения }\end{array}$ \\
\hline Всего & 69,6 & 1407,7 & 100,4 & 1320,8 \\
\hline Женщины & 21,1 & 858,8 & 29,5 & 783,1 \\
\hline Мужчины & 48,4 & 1954,9 & 70,9 & 1853,3
\end{tabular}


Более низкий социально-экономический статус также приводит к росту смертности и связанных с алкоголем причин - в 1,5-2 раза по сравнению со всеми причинами (Probst et al., 2014).

На потерянные годы здоровой жизни вследствие употребления алкоголя приходится около 99,2 млн лет жизни (DALY) (Gray, 2018). Из них 82 млн лет утрачены вследствие смертности (YLL), а 17,2 млн - вследствие инвалидности (YLD) (Degenhardt et al., 2018).

Наибольшее число смертей на душу населения от причин, связанных алкоголем, в 2016 г. приходилось на регион Восточной Европы — более 10 млн случаев (4245,6 на 100 тыс.), повлекшее 12,3 млн DALY (4730,9 на 100 тыс., или 13,8\% мирового бремени). Это в 2,5 раза больше, чем в Западной Европе (1921,8 и 6,3\% соответственно) и в 4,5 раза, чем в Северной Америке (1139,3 и 4,5\%) (Degenhardt et al., 2018). В России показатели потерь от алкоголя в 3 раза превышают среднемировые (таблица 2).

Таблица 2

Глобальное бремя заболеваний, вызванных алкоголем, в 2016 г. в мире и РФ, на 100 тыс. населения (Degenhardt, L., Charlson, F., Ferrari, A., et al., 2018)

\begin{tabular}{l|c|c}
\multicolumn{1}{c|}{ Показатель } & Мир & Россия \\
\hline Число случаев смерти & 40,4 & 119,3 \\
\hline DALY & 1352,0 & 4942,7 \\
\hline YLD (вследствие инвалидности) & 231,9 & 638,1 \\
\hline YLL (вследствие преждевременной смертности) & 1120,1 & 4304,6
\end{tabular}

В РФ в структуре потерь психические и поведенческие расстройства занимают 9\% ГББ и их доля стабильна на протяжении 2000-х гг. (табл. 3). Нарушения употребления алкоголя составляют $3 \%$ ГББ. Наблюдается рост бремени как психических расстройств, так и последствий алкоголизма в группе молодежи от 15 до 29 лет (на 19 и 10\% соответственно).

Статистические показатели алкоголизации. Оценив масштабы экономических потерь, вызванных алкоголем, рассмотрим степень актуальности проблемы алкоголизма в нашей стране. Алкоголизация как статистическая совокупность может характеризоваться системой показателей. Эпидемиологические показатели демонстрируют позитивные тенденции в отношении алкогольной зависимости. Так, по сравнению с 1990 г. заболеваемость алкоголизмом и алкогольными психозами в стране сократилась в 2,3 раза (таблица 4). В Вологодском регионе показатель также снижается, но меньшими темпами (в 1,7 раза). Пиковые значения наблюдались в 1995 г. (начавшееся вследствие прекращения ограничения продажи спиртных напитков в 1985 г.) и 2005 г. (вследствие увеличения среднедушевого потребления алкоголя). За 2015 г. также наблюдался скачок заболеваемости алкоголизмом в РФ на $10 \%$, а в Вологодском регионе - на $50 \%$. 
Потери DALY от психических и поведенческих расстройств, а также вследствие алкогольной зависимости в России в период 2000-2016 гг., процент к общей массе потерь от всех заболеваний (рассчитано автором на основе баз данных GLOBAL HEALTH ESTIMATES 2000, 2010, 2016 SUMMARY TABLES. URL: http://www.who.int/healthinfo/global_burden disease/en)

\begin{tabular}{|c|c|c|c|c|c|c|c|c|c|c|c|c|}
\hline \multirow[b]{2}{*}{ Расстройство } & \multicolumn{4}{|c|}{ Все возрасты } & \multicolumn{4}{|c|}{ 15-29 лет } & \multicolumn{4}{|c|}{ 30-49 лет } \\
\hline & ஓ ণ & $\stackrel{\circ}{\circ}$ & $\stackrel{\circ}{\circ}$ & 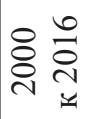 & ஓ̊ & $\stackrel{\circ}{\stackrel{\circ}{\circ}}$ & $\stackrel{0}{\circ}$ & 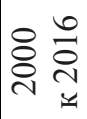 & ஓ & $\stackrel{\circ}{\stackrel{0}{\circ}}$ & 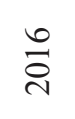 & 官 \\
\hline $\begin{array}{l}\text { Психические } \\
\text { и поведенческие }\end{array}$ & 9,0 & 8,9 & 9,1 & 101 & 20,1 & 22,0 & 23,9 & 119 & 15,4 & 15,2 & 16,4 & 107 \\
\hline $\begin{array}{l}\text { Нарушение } \\
\text { употребления } \\
\text { алкоголя }\end{array}$ & 3,9 & 3,4 & 3,2 & 81 & 5,4 & 5,6 & 6,0 & 110 & 8,4 & 7,1 & 6,9 & 81 \\
\hline
\end{tabular}

Таблица 4

Заболеваемость алкоголизмом и алкогольными психозами

в России и Вологодской области, на 100 тыс. населения

(Федеральная служба государственной статистики: официальный сайт. URL: www.gks.ru)

\begin{tabular}{l|c|c|c|c|c|c|c|c|c|c|c} 
& $\mathbf{1 9 9 0}$ & $\mathbf{1 9 9 5}$ & $\mathbf{2 0 0 0}$ & $\mathbf{2 0 0 5}$ & $\mathbf{2 0 1 0}$ & $\mathbf{2 0 1 1}$ & $\mathbf{2 0 1 2}$ & $\mathbf{2 0 1 3}$ & $\mathbf{2 0 1 4}$ & $\mathbf{2 0 1 5}$ & $\mathbf{2 0 1 6}$ \\
\hline $\begin{array}{l}\text { Российская } \\
\text { Федерация }\end{array}$ & 152,0 & 155,5 & 130,6 & 146,2 & 107,7 & 96,6 & 85,7 & 78,2 & 64,5 & 70,8 & 64,8 \\
\hline $\begin{array}{l}\text { Вологодская } \\
\text { область }\end{array}$ & 113,1 & 160,3 & 98,8 & 150,2 & 104,2 & 99,9 & 86,3 & 71 & 47,2 & 70,2 & 64,3
\end{tabular}

В 2017 г. лидировали по заболеваемости алкоголизмом и алкогольными психозами в основном самые малонаселенные регионы (от 0,07 до 0,3 чел. на кв. км): Чукотский $\mathrm{AO}(252,9$ на 100 тыс. населения), Магаданская область $(167,6)$, Республика Саха $(139,0)$, Хабаровский край $(128,3)$, Ненецкий АО $(120,6)$, Сахалинская область $(113,5)$.

Отдельного внимания заслуживает показатель заболеваемости алкогольными психозами, которые формируются на второй-третьей стадии алкоголизма (как правило, спустя 2-5 лет страдания алкоголизмом). Главным и обязательным фактором их возникновения является многодневное злоупотребление алкоголем на протяжении ряда лет. Частота их возникновения отражает уровень алкоголизации населения 
(так называемую алкогольную ситуацию в стране) (Гофман, Орлова, Меликсетян, 2010). Почти каждый пятый госпитализированный больной алкогольной зависимостью - это больной алкогольным психозом.

Всплески заболеваемости данным диагнозом отмечены в середине 1990-х и середине 2000-х гг, после чего наблюдается стабильный спад (рис. 1).

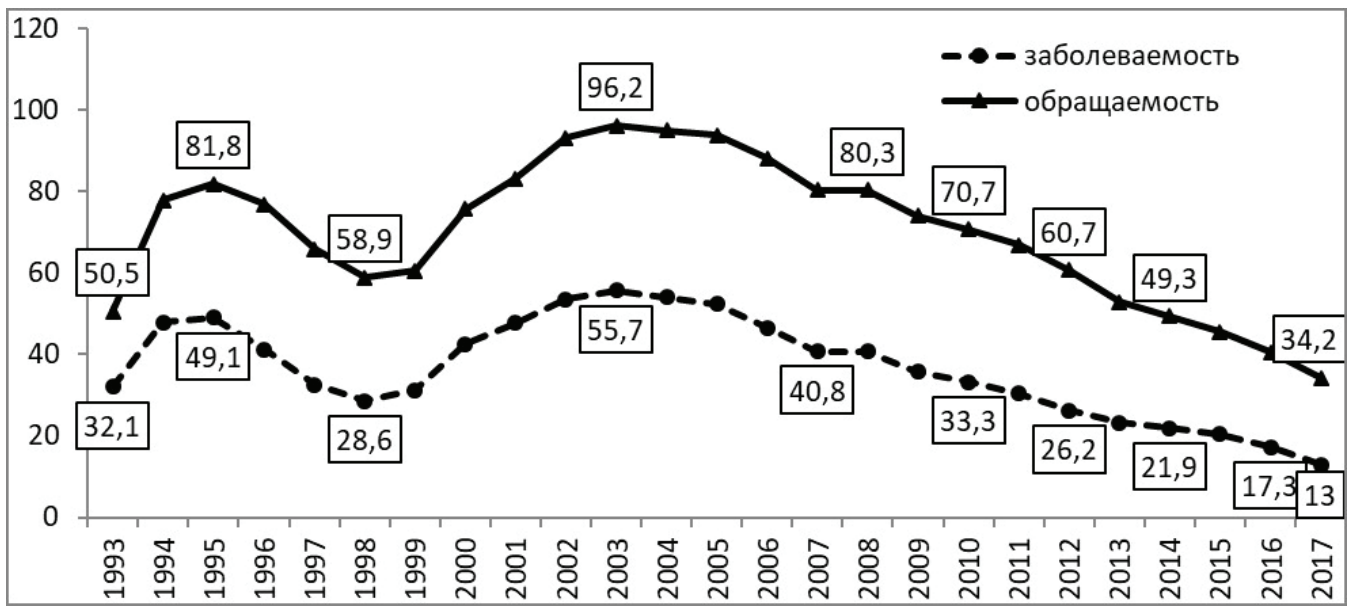

Рисунок 1 - Заболеваемость алкогольными психозами в РФ и число обратившихся за наркологической помощью с диагнозом «алкогольный психоз» в период 1993-2017 гг., на 100 тыс. населения

Обращаемость за наркологической помощью с диагнозом «алкогольный психоз» испытывает аналогичные тенденции (рис. 1).

Таблица 5

Заболеваемость алкогольными психозами в федеральных округах РФ в 2017 г., на 100 тыс. населения (Социально значимые заболевания..., 2018: 44-57)

\begin{tabular}{l|c|l|c}
\multicolumn{2}{c|}{ Макрорегионы РФ } & \multicolumn{2}{c}{ Субъекты СЗФО } \\
\hline $\begin{array}{l}\text { Российская Федерация } \\
\begin{array}{l}\text { Дальневосточный федеральный } \\
\text { округ }\end{array}\end{array}$ & 13,0 & Ненецкий автономный округ & 34,1 \\
\hline Уральский федеральный округ & 18,4 & Калининградская область & 30,7 \\
\hline Приволжский федеральный округ & 16,2 & Республика Карелия & 25,5 \\
\hline Сибирский федеральный округ & 14,9 & Вологодская область & 24,7 \\
\hline $\begin{array}{l}\text { Северо-Западный федеральный } \\
\text { округ }\end{array}$ & 13,6 & Новгородская область & 19,6 \\
\hline
\end{tabular}




\begin{tabular}{l|c|l|c}
\multicolumn{2}{c|}{ Макрорегионы РФ } & \multicolumn{2}{c}{ Субъекты СЗФО } \\
\hline Центральный федеральный округ & 11,6 & Мурманская область & 17,8 \\
\hline Южный федеральный округ & 6,6 & Республика Коми & 17,4 \\
\hline $\begin{array}{l}\text { Северо-Кавказский федеральный } \\
\text { округ }\end{array}$ & 2,3 & Архангельская область & 12,4 \\
\hline $\begin{array}{l}\text { Северо-Западный федеральный } \\
\text { округ }\end{array}$ & 13,6 & Ленинградская область & 9,3 \\
\cline { 3 - 5 } & & г. Санкт-Петербург & 6
\end{tabular}

В десятку лидеров по заболеваемости алкогольными психозами в 2017 г. вошли Чукотский (62,2 на 100 тыс.), Ненецкий $(34,1)$ и Ямало-Ненецкий $(32,8)$ автономные округа, Магаданская $(33,7)$ и Калининградская $(30,7)$, Курганская $(26,8)$ области, Еврейская автономная область $(30,4)$, Пермский $(31,2)$ и Хабаровский $(30,0)$ края, Республика Марий Эл $(26,6)$. Часть из них также являются регионами с низкой плотностью населения.

Северо-Западный ФО занимает третье место среди макрорегионов по заболеваемости алкогольными психозами, после Дальневосточного и Уральского (табл. 5). В СЗФО по данному показателю лидируют Ненецкий АО, Калининградская и Псковская области. В Вологодском регионе число лиц с впервые в жизни установленным диагнозом в 1,5 раза превышает средний по стране и по СЗФО и в 2017 г. составил 19,6 на 100 тысяч населения (30-е место в РФ). Это говорит о неблагоприятной алкогольной ситуации в регионе.

Заболеваемость алкогольными психозами в РФ только за последнее десятилетие снизилась в 3 раза, в СЗФО — в 3,5 раза (таблица 6).

Таблица 6

Выявлено впервые с алкогольными психозами, на 100 тыс. населения.

Составлено автором на основе статистических сборников

Медицинского информационно-аналитического центра Департамента здравоохранения Вологодской области за 2008-2017 гг., а также по:

(Социально значимые заболевания..., 2018)

\begin{tabular}{l|c|c|c|c|c|c|c|c}
\multicolumn{1}{|c|}{ Территория } & $\mathbf{2 0 0 8}$ & $\mathbf{2 0 0 9}$ & $\mathbf{2 0 1 1}$ & $\mathbf{2 0 1 3}$ & $\mathbf{2 0 1 4}$ & $\mathbf{2 0 1 5}$ & $\mathbf{2 0 1 6}$ & $\mathbf{2 0 1 7 *}$ \\
\hline Россия & 40,8 & 35,7 & 30,5 & 23,4 & 21,9 & 20,5 & 17,4 & 13,0 \\
\hline СЗФО & 48,2 & 44,9 & 35,5 & 24,3 & 23,7 & 20,6 & 18,6 & 13,6 \\
\hline $\begin{array}{l}\text { Вологодская } \\
\text { область }\end{array}$ & 57,1 & 52,1 & 51,5 & 34,3 & 33,5 & 35,0 & 29,6 & 19,6
\end{tabular}

Еще одним ярким статистическим показателем проблемы алкоголизма в стране является уровень смертности от случайных алкогольных отравлений. В 2018 г. более 5,5 тыс. жителей России погибли по данной причине, еще более 1,5 тыс. - 
от отравлений и воздействия алкоголем с неопределенными намерениями ${ }^{1}$. Основные тренды смертности от случайных отравлений алкоголем в целом совпадают с заболеваемостью алкогольными психозами, демонстрируя пики в 1995 и 2005 гг. (рис. 2). Однако в период 2013-2014 гг. отмечен рост смертности на 50\% по сравнению с 2012 г.

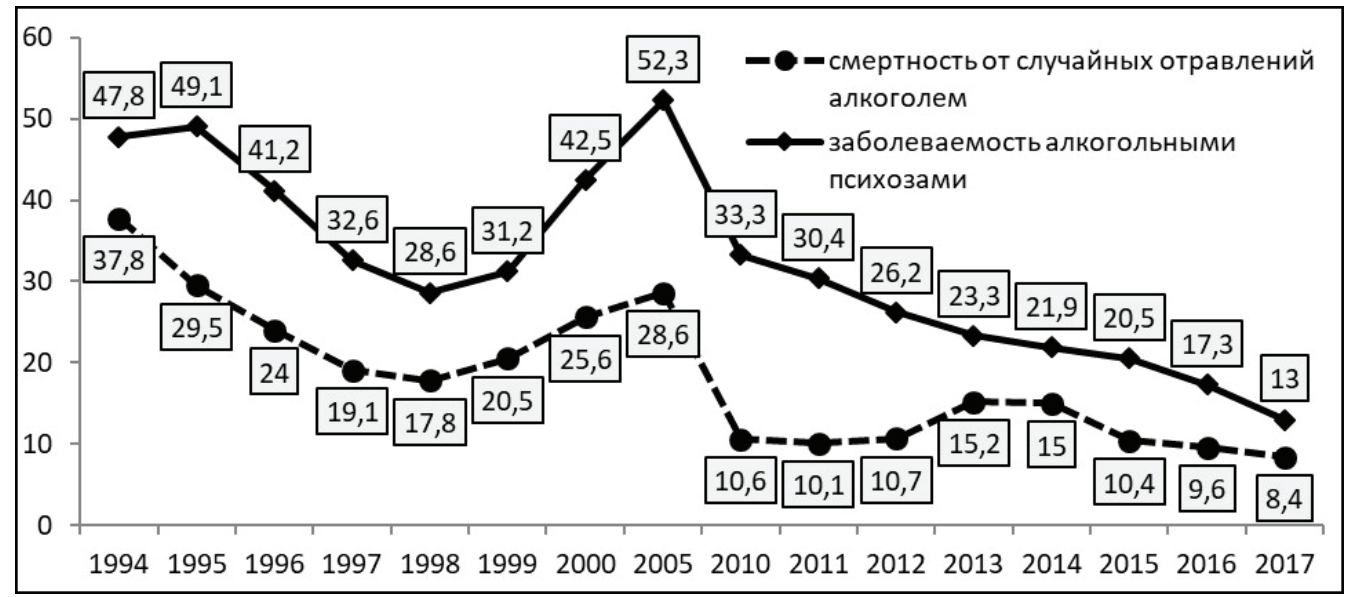

Рисунок 2 - Динамика смертности от случайных отравлений алкоголем

и заболеваемости алкогольными психозами в РФ в период 1994-2017 гг., на 100 тыс. населения

Мужчины в 4 раза чаще погибают от случайных отравлений алкоголем, чем женщины (рис. 3).

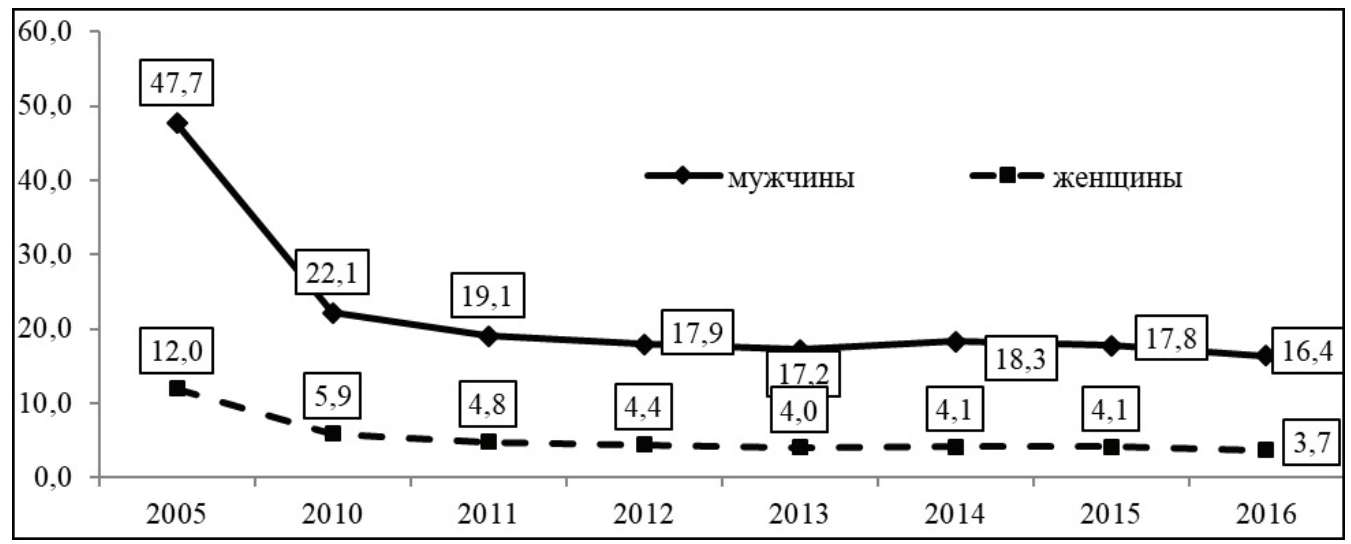

Рисунок 3 - Смертность в РФ мужчин и женщин от случайных алкогольных отравлений в период 2005-2016 гг., на 100 тыс. населения

(Федеральная служба государственной статистики: официальный сайт. URL: www.gks.ru)

1 Сведения о смертности населения по причинам смерти в Российской Федерации за январь-декабрь 2018 года. URL: http://www.gks.ru/free_doc/2018/demo/t3_3.xls (дата обращения: 01.07.2019). 
Смертность от случайных отравлений алкоголем является одной из предотвратимых причин. Как правило, она вызвана отравлением фальсификатом либо является следствием передозировки, что во многом зависит от уровня потребления населением крепких спиртных напитков. К сожалению, официальной статистики по этому поводу не существует. Мы можем только предположить объем потребления исходя из объема продаваемого населению алкоголя. Разумеется, этот показатель лишь частично отражает реальное потребление, так как он не учитывает столь популярное в нашей стране домашнее производство спиртных напитков, а также потребление нелегальной алкогольной продукции и суррогатов.

Данные социологических исследований могут дополнить информацию об истинном положении дел. Так, согласно опросу, проведенному ВолНЦ РАН в 2019 г., каждый пятый житель «ежедневно» или «по выходным» употребляет пиво, а каждый 12 -й — крепкие напитки. Около $60 \%$ населения Вологодской области совсем не пьют пиво, некрепленые вина и крепкие спиртные напитки, а 74\% - крепленые вина.

По данным официальной статистики, в целом продажа алкогольных напитков в России по сравнению с 2005 г. снижена как в абсолютном алкоголе, так и в относительном (на душу населения) и в процентах от общего объема оборота (на треть; таблица 7). К 2010 г. наблюдался рост продажи коньяков, вина и пива.

Продажа населению России алкогольных напитков в 2005-2016 гг.

(Торговля в России — 2017, 2018)

\begin{tabular}{l|c|c|c|c|c}
\multicolumn{1}{r|}{ Алкогольные напитки } & $\mathbf{2 0 0 5}$ & $\mathbf{2 0 1 0}$ & $\mathbf{2 0 1 4}$ & $\mathbf{2 0 1 5}$ & $\mathbf{2 0 1 6}$ \\
\hline В абсолютном алкоголе: & & & & & \\
\hline всего, млн. дкл & 133,2 & 127,6 & 110,5 & 99,2 & 96,8 \\
\hline на душу населения, л & 9,3 & 8,9 & 7,6 & 6,8 & 6,6 \\
\hline В натуральном выражении, млн. дкл: & & & & & \\
\hline водка и ликероводочные изделия & 203,5 & 157,8 & 112,4 & 97,2 & 96,6 \\
\hline коньяки, коньячные напитки & 6,8 & 11,1 & 11,5 & 10,6 & 10,3 \\
\hline напитки слабоалкогольные ( & н/д & 31,9 & 17,8 & 10,0 & 8,8 \\
\hline винодельческая продукция & 84,9 & 103,4 & 90,4 & 86,9 & 84,9 \\
\hline шампанские и игристые вина & 19,4 & 27,3 & 26,4 & 23,6 & 22,0 \\
\hline пиво & 892,1 & 1004,0 & 895,9 & 810,2 & 780,6 \\
\hline В процентах от общего объема оборота & 9,6 & 7,6 & 7,1 & 6,9 & 6,8
\end{tabular}

Изучая географию продаж алкоголя в РФ, можно сделать следующие выводы. Пиво наиболее продаваемо в Уральском и Центральном федеральных округах (та- 
блица 8), водка - в Дальневосточном и Сибирском, вино и коньяк - в Северо-Западном и Центральном.

Таблица 8

Продажа алкогольных напитков в федеральных округах РФ в 2017 г., литров на душу населения в год (Регионы России..., 2018)

\begin{tabular}{l|c|c|c|c|c}
\multicolumn{1}{c|}{ Макрорегионы } & Водка & Коньяк & Вино & $\begin{array}{c}\text { Игристые, } \\
\text { шампанские }\end{array}$ & Пиво \\
\hline Российская Федерация & 5,5 & 0,7 & 6,3 & 1,2 & 49,3 \\
\hline Центральный ФО & 6,2 & 0,9 & 7,4 & 1,5 & 56,4 \\
\hline Северо-Западный ФО & 7,8 & 1,2 & 9,1 & 1,7 & 49,1 \\
\hline Южный ФО & 3,5 & 0,7 & 5,7 & 1,2 & 40,8 \\
\hline Северо-Кавказский ФО & 1,0 & 0,2 & 1,3 & 0,3 & 10,2 \\
\hline Приволжский ФО & 6,1 & 0,5 & 5,7 & 0,7 & 54,2 \\
\hline Уральский ФО & 5,4 & 0,7 & 6,4 & 1,2 & 56,8 \\
\hline Сибирский ФО & 4,8 & 0,4 & 5,4 & 0,9 & 47,7 \\
\hline Дальневосточный ФО & 8,9 & 0,9 & 6,7 & 1,9 & 55,3
\end{tabular}

В среднем в России в 2017 г. продавалось 5,5 литра водки в год на одного жителя, включая детей, а это значит 7 литров - на одного взрослого (0,6 л в месяц). Лидерами являются Сахалинская, Магаданская области и республики Коми и Карелия (более 12 литров водки в год). Магаданская область находится на втором месте и по продаже коньяка, после Мурманской. Ненецкий АО, Карелия и Сахалинская область лидируют по продаже вина и пива. В среднем в России и СЗФО продается 49 литров пива на душу населения в год, вдвое больше - в республиках Адыгея (98) и Татарстан (93), Еврейской АО (86) и в Камчатском крае (82). Субъекты Северо-Кавказского федерального округа традиционно замыкают список по продажам всех алкогольных напитков.

В Вологодской области показатели продажи некоторых алкогольных напитков выше, чем в целом по стране (водки - в два раза, вина - на треть, пива — на 10\%; табл. 9). Поскольку водки и коньяка в регионе продается 10,6 литра на душу населения, на одного взрослого приходится 8,3 литра в год. Если обратить внимание на упомянутые выше социологические опросы, согласно которым две трети жителей не употребляют крепкие спиртные напитки, то на оставшуюся треть приходится по 2 литра ежемесячно. Продажа шампанского и игристых вин в Вологодском регионе ниже российского и среднего по СЗФО.

В СЗФО Мурманская область лидирует по продажам коньяка, пива и шампанских вин, Коми - по водке, а Ненецкий АО - по вину. Самые северные субъекты округа традиционно демонстрируют больший интерес к чрезмерному употреблению алкоголя. 
Таблица 9

Продажа алкогольных напитков в СЗФО в 2017 г., литров на душу населения в год. Рассчитано автором по (Регионы России..., 2018)

\begin{tabular}{l|c|c|c|c|c}
\multicolumn{1}{c|}{ Регион } & Водка & Коньяк & Вино & $\begin{array}{c}\text { Игристые, } \\
\text { шампанские }\end{array}$ & Пиво \\
\hline Россия & 5,5 & 0,7 & 6,3 & 1,2 & 49,3 \\
\hline СЗФО & 7,8 & 1,2 & 9,1 & 1,7 & 49,1 \\
\hline Республика Карелия & 11,8 & 1,3 & 12,2 & 1,3 & 57,7 \\
\hline Республика Коми & 12,3 & 1,0 & 9,7 & 1,4 & 64,0 \\
\hline Архангельская область & 11,1 & 0,9 & 9,2 & 1,6 & 50,1 \\
\hline Ненецкий АО & 10,5 & 1,0 & 13,1 & 2,2 & 51,9 \\
\hline Вологодская область & 9,9 & 0,7 & 9,2 & 0,9 & 54,7 \\
\hline Калининградская область & 4,2 & 0,8 & 7,3 & 0,9 & 32,1 \\
\hline Ленинградская область & 9,0 & 1,5 & 9,7 & 1,6 & 54,9 \\
\hline Мурманская область & 9,8 & 1,8 & 8,7 & 2,3 & 70,8 \\
\hline Новгородская область & 7,4 & 1,0 & 9,5 & 1,1 & 55,1 \\
\hline Псковская область & 6,2 & 0,8 & 9,5 & 1,3 & 55,6 \\
\hline г. Санкт-Петербург & 5,7 & 1,4 & 8,7 & 2,1 & 40,9
\end{tabular}

Наименьшее количество алкоголя в СЗФО продается в Калининградской области. Однако смертность населения в данном регионе от случайных отравлений алкоголем (в 2017 г. - 10,1 на 100 тыс. населения) более чем в 2 раза превышает средний по стране $(4,6)$. По заболеваемости алкогольными психозами регион находится на шестом месте в России, по уровню трезвости ${ }^{1}$ - на 46-м месте (таблица 10). Косвенно это может свидетельствовать об активном нелегальном, в том числе «домашнем» производстве пива, вина и других алкогольных напитков.

\footnotetext{
1 Федеральный проект «Трезвая Россия» подготовлен командой специалистов: экспертов, социологов, юристов, экономистов, историков, психологов и журналистов. При составлении «рейтинга трезвости» ими были учтены следующие показатели официальной статистики: смертность от случайных отравлений алкоголем, численность больных в ЛПУ с диагнозом «алкоголизм» и «алкогольные психозы», число преступлений в состоянии алкогольного опьянения, продано алкогольной продукции, число правонарушений, связанных с незаконным производством и оборотом этилового спирта и алкоголя, количество часов запрета продажи алкоголя ежедневно и количество дней запрета (Рейтинг трезвости регионов - 2017).
} 
Субъекты СЗФО в «Рейтинге Трезвости регионов России - 2017»

\begin{tabular}{l|c|c}
\multicolumn{1}{c|}{$\quad$ Регионы } & балл & место \\
\hline Ненецкий автономный округ & 46,6 & 84 \\
\hline Республика Коми & 40,19 & 73 \\
\hline Архангельская область & 37,48 & 64 \\
\hline Вологодская область & 37,28 & 63 \\
\hline Республика Карелия & 36,75 & 61 \\
\hline Псковская область & 35,98 & 50 \\
\hline Калининградская область & 35,41 & 46 \\
\hline г. Санкт-Петербург & 34,38 & 37 \\
\hline Новгородская область & 34,22 & 35 \\
\hline Ленинградская область & 33,39 & 26 \\
\hline Мурманская область & 30,09 & 14
\end{tabular}

Провоцирует чрезмерное потребление алкоголя и обострение криминальной обстановки. По данным Росстата, каждое пятое-шестое преступление в 20162018 гг. совершено в состоянии алкогольного опьянения (таблица 11). Причем это происходит в два раза чаще, чем например, во второй половине 2000-х гг.

Таблица 11

Число преступлений, совершенных в состоянии опьянения, тыс. (по данным gks.ru)

\begin{tabular}{l|c|c|c|c|c|c|c}
\multicolumn{1}{c|}{ Показатель } & $\mathbf{2 0 0 0}$ & $\mathbf{2 0 0 5}$ & $\mathbf{2 0 1 0}$ & $\mathbf{2 0 1 5}$ & $\mathbf{2 0 1 6}$ & $\mathbf{2 0 1 7}$ & $\mathbf{2 0 1 8}$ \\
\hline $\begin{array}{l}\text { Число преступлений, } \\
\text { совершенных: }\end{array}$ & 2952,4 & 3554,7 & 2628,8 & 2388,5 & 2160,1 & 2058,8 & 1991,5 \\
\hline $\begin{array}{l}\text { в состоянии алкоголь- } \\
\text { ного опьянения }\end{array}$ & 442,7 & 311,8 & 237,3 & 401,0 & 440,2 & 378,0 & 351,6 \\
\hline $\begin{array}{l}\text { в состоянии наркоти- } \\
\text { ческого опьянения }\end{array}$ & 18,9 & 8,1 & 14,8 & 33,2 & 28,2 & 23,9 & 14,6 \\
\hline $\begin{array}{l}\text { Процент от числа всех } \\
\text { преступлений }\end{array}$ & 15,6 & 9,0 & 9,6 & 18,2 & 21,7 & 19,5 & 18,4
\end{tabular}

\section{Выводы и обсуждение}

Таким образом, с одной стороны, можно говорить о благоприятных тенденциях снижения заболеваемости алкоголизмом и алкогольными психозами, смертности от случайных отравлений алкоголем, сокращения объемов продаж спиртных напит- 
ков как в целом по стране, так и в СЗФО и в Вологодской области (но меньшими темпами) по сравнению с серединой 2000-х гг.

С другой стороны, уровень смертности в России от заболеваний, вызванных алкоголем, остается крайне высоким (119,3 на 100 тыс. населения). Нашу страну опережают только Королевство Лесото $(292,8)$, Центральная Африканская Республика $(228,4)$, Монголия $(126,7)$, Румыния $(124,1)$, Украина $(123,6)$ и Уганда $(122,2)$ (Degenhardt et al., 2018).

Настораживает и факт роста уровня смертности от заболеваний, связанных с потреблением алкоголя, в группе молодежи. Соответственно возрастает и экономическое бремя в данной возрастной категории.

Заболеваемость алкогольными психозами и объемы продаж алкоголя на душу населения в СЗФО и конкретно в Вологодской области выше среднероссийского, что может говорить о недостаточно эффективной системе лечения алкоголизма и реабилитации пациентов.

На данный момент алкогольная проблема в России решается следующим образом. Был введен практически полный запрет рекламы спиртного, повышены акцизы и минимальные цены на алкоголь, значительно увеличены штрафы и сроки наказания за вождение в нетрезвом состоянии, запрещено употребление алкоголя в общественных местах, законодательно признано алкогольным напитком пиво, запрещены производство и продажа так называемых «энергетиков», введено ограничение времени продаж спиртных напитков. Важным направлением борьбы с «зеленым змием» являются предпринимаемые усилия по развитию и пропаганде спорта (в т.ч. проведение Олимпийских игр, Чемпионата мира по футболу и др.), строительству спортивных сооружений по всей стране.

Разумеется, все эти шаги способствуют решению проблемы алкоголизма, но не в полной мере. Также, к сожалению, «приходится констатировать, что за последние десятилетия в стране складывается антикультура пития и разрушаются старинные питейные традиции. Люди стали пить и в будни, и в праздники. Привычным становится потребление алкоголя среди подростков и женщин. Население начинает употреблять не только алкогольные напитки, но и парфюмерные изделия, медицинские настойки и другие препараты, содержащие алкоголь. Все это является свидетельством того, что потребность населения в алкоголе обладает большой инерционностью» (Ерпылов, 2015: 32).

Для преодоления проблемы в России и в дальнейшем необходимо разрабатывать антиалкогольную федеральную программу; заниматься пропагандой здорового образа жизни, привлекая СМИ, школы, высшие учебные заведения, работодателей, медицинских работников; бороться с коррупцией и алкогольными монополиями.

Важно отметить, что повышение цен на алкоголь стимулирует его нелегальную продажу (Семьянинов, 2012). Государство не должно стремиться пополнить бюджет сборами с крепкого алкоголя. Его потребление, а следовательно, и сборы должны быть низкими. Изначально решение проблемы алкоголизма будет требовать от государства немалых расходов, но важно отметить, что трезвая нация в будущем 
принесет больше доходов, нежели акцизные сборы с продажи алкогольной продукции в данный момент (Черемисина, Ивлев, Талаев, 2014).

Немаловажным является и привлечение общественных организаций в процесс формирования и тиражирования эффективных технологий профилактики, совершенствования системы наркологической помощи. Институты гражданского общества, в том числе некоммерческие организации, находясь в тесной взаимосвязи с органами государственной власти, могут осуществлять не только социальную, реабилитационную помощь, подготовку кадров, но и активно участвовать в выработке нормативно-правовых актов на государственном уровне и содействовать их принятию.

С экономической точки зрения создание трезвой нации - это долгосрочное инвестирование государства в здоровье собственных граждан, в человеческий капитал и национальную безопасность.

\section{БИБЛИОГРАФИЧЕСКИЙ СПИСОК}

Гофман А.Г., Орлова М.А., Меликсетян А.С. Алкогольные психозы: клиника, классификация. Социальная и клиническая психиатрия, 2010, XX(1), 5-12.

Ерпылов А.А. Алкоголизм как социальная проблема российского общества. Теория и практика сервиса: экономика, социальная сфера, технологии, 2015, №. 4, 31-34.

Регионы России. Социально-экономические показатели - 2018 г.: статистический сборник. URL: http://www.gks.ru/bgd/regl/b18_14p/Main.htm.

Рейтинг трезвости регионов — 2017. Трезвая Россия. URL: http://www.trezvros.ru/ calendar/524 (дата обращения: 01.07.2019).

Семьянинов П.В., Семьянинов В.П. О тенденциях глобализации. Социально-экономические явления и процессы, 2012, No. 1, 152-161.

Социально значимые заболевания населения России в 2017 году: Статистические материалы. М., 2018.

Торговля в России — 2017: Статистический сборник. URL: http://www.gks.ru/bgd/ regl/b17_58/Main.htm.

Черемисина Н.В., Ивлев М.И., Талалаев Д.Д. Алкоголизм: глобальная проблема современной России. Социально-экономические явления и процессы, 2014, 9(10), 164-168.

Degenhardt L., Charlson F., Ferrari A., et al. The global burden of disease attributable to alcohol and drug use in 195 countries and territories, 1990-2016: a systematic analysis for the Global Burden of Disease Study 2016. Lancet Psychiatry, 2018, No. 5, 987-1012.

Gray C. Mixed up: alcohol and society. The Lancet psychiatry, 2018, 5(12), 970. doi: 10.1016/S2215-0366(18)30432-2.

Probst Ch., Roerecke M., Behrendt S., Rehm Ju. Socioeconomic differences in alcoholattributable mortality compared with all-cause mortality: a systematic review and metaanalysis arlotte. International Journal of Epidemiology, 2014, 43(4), 1314-1327. doi: 10.1093/ije/dyu043. 
Rehm J., Baliunas D., Borges G.L., et al. The relation between different dimensions of alcohol consumption and burden of disease: an overview. Addiction, 2010, No. 105, 817843.

Rehm J., Gmel G.E. Sr., Gmel G., et al. The relation between different dimensions of alcohol consumption and burden of disease: an update. Addiction, 2017, No. 112, 9681001.

\section{REFERENCES}

Hoffman, A.G., Orlova, M.A., Meliksetyan, A.S. (2010). Alkogol'nye psihozy: klinika, klassifikaciya. [Alcoholic psychosis: clinic, classification]. Social'naya $i$ klinicheskaya psihiatriya [Social and Clinical Psychiatry], XX(1), 5-12.

Erpylov, A.A (2015). Alkogolizm kak social'naya problema rossijskogo obshchestva [Alcoholism as a social problem of Russian society]. Teoriya i praktika servisa: ekonomika, social'naya sfera, tekhnologii [Theory and practice of service: economics, social sphere, technology], no 4, 31-34.

Regiony Rossii. Social'no-ekonomicheskie pokazateli - 2018 g.: statisticheskij sbornik (2018). [Region of Russia. Socio-economic indicators-2018: statistical compendium]. Available at: http://www.gks.ru/bgd/regl/b18_14p/Main.htm.

Rejting trezvosti regionov — 2017 [Ranking of sobriety regions - 2017]. Trezvaya Rossiya [Sober Russia]. Available at: http://www.trezvros.ru/calendar/524 (date accessed: 01.07.2019).

Semyaninov, P.V., Semianinov, V.P. (2012). O tendenciyah globalizacii [On globalization trends]. Social'no-ekonomicheskie yavleniya i processy [Socio-economic phenomen and processes], no 1, 152-161.

Social'no znachimye zabolevaniya naseleniya Rossii v 2017 godu: Statisticheskie materialy (2018) [Socially significant diseases of the Russian population in 2017: Statistical materials]. M.

Torgovlya v Rossii - 2017: Statisticheskij sbornik (2018) [Trade in Russia-2017: Statistical collection]. Available at: http://www.gks.ru/bgd/regl/b17_58/Main.htm.

Cheremisina, N.V., Ivlev, M.I., Talalaev, D.D. (2014). Alkogolizm: global'naya problema sovremennoj Rossii [Alcoholism: the global problem of modern Russia]. Social'no-ekonomicheskie yavleniya i processy [Socio-economic phenomen and processes], 9(10), 164 68.

Degenhardt, L., Charlson, F., Ferrari, A., et al. (2018). The global burden of disease attributable to alcohol and drug use in 195 countries and territories, 1990-2016: a systematic analysis for the Global Burden of Disease Study 2016. Lancet Psychiatry, no 5, 987-1012.

Gray, C. (2018). Mixed up: alcohol and society. Lancet psychiatry, 5(12), 970. Doi: 10.1016/S2215-0366(18)30432-2.

Probst, Ch., Roerecke, M., Behrendt, S., et al. (2014). Socioeconomic differences in alcohol-attributable mortality compared with all-cause mortality: a systematic review and meta-analysis arlotte. International Journal of Epidemiology, 43(4), 1314-1327. doi: 10.1093/ije/dyu043. 
Rehm, J., Baliunas, D., Borges, G.L., et al. (2010). The relation between different dimensions of alcohol consumption and burden of disease: an overview. Addiction, no 105, 817-843.

Rehm, J., Gmel, G., Gmel, G., et al. (2017). The relation between different dimensions of alcohol consumption and burden of disease: an update. Addiction, no 112, 968-1001. 